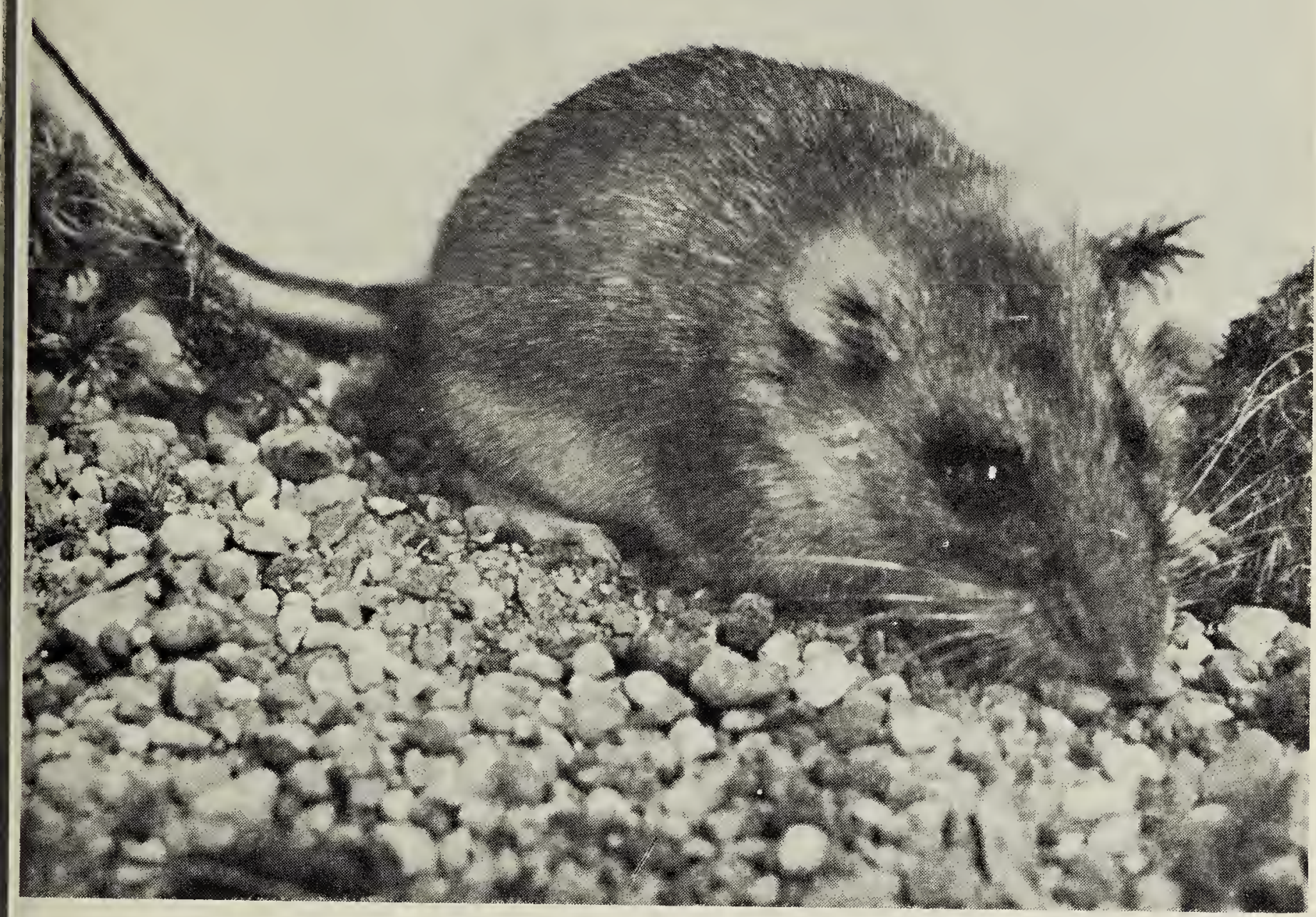

Figure 2. Abnormal "earless" Peromyscus.

Photo by D. J. Andrews

born on April 5, 1967 all showed normal ear development.

To date, crosses among "earless" litter mates have produced seven young, all with normal ears. These breeding data suggest that the unusual ear development of the "earless" animals has resulted from a physiological abnormality of the female parent during pregnancy; however further breeding is being continued to discover whether the observed abnormality is genetic.

During the summer of 1966, more than 200 Peromyscus were captured in live traps from the same general region which produced the parents of the "earless" animals. All had normal ear development. As deer mice are an important food source for many avian and mammalian predators, they are dependent for survival on acute visual and auditory reception. Animals which lack normal ear development would therefore be more susceptible to predation and would be unlikely to survive to breeding maturity under field conditions.

\section{BLACK BEAR AT ROCANVILLE}

by Mrs. D. Sutton, Rocanville

In early May this year a large bear was seen several times about two and a half miles east of Rocanville. Ray Birkenshaw said that the animal was black. Ernest Holland, who saw it at close range on the grid-road allowance, called it brown "at least the hairs had a brown tinge at the ends".

Bears have been reported periodically in this district but previously they were closer to the Qu'Appelle Valley. The bear seen here this year was not far from the garbage dump so probably he had been rummaging there. 